\title{
FIP1L1 wt Allele
}

National Cancer Institute

\section{Source}

National Cancer Institute. FIP1L1 wt Allele. NCI Thesaurus. Code C97455.

Human FIP1L1 wild-type allele is located in the vicinity of $4 \mathrm{q} 12$ and is approximately 918 $\mathrm{kb}$ in length. This allele, which encodes pre-mRNA 3'-end-processing factor FIP1 protein, plays a role in the mediation of mRNA polyadenylation. A chromosomal deletion del(4q12) fuses this gene and the PDGFRA gene and is associated with chronic eosinophilic leukemia. 